DOI: $10.17805 /$ trudy.2015.4.4

\title{
СОВРЕМЕННОЕ СОСТОЯНИЕ РЫНКА ТРУДА МОЛОДЕЖИ В РОССИИ
}

\author{
Л. О. Ромашова \\ (Московский гуманитарный университет)
}

Аннотация: В статье анализируется рынок труда молодежи. Выделяются причины, вызывающие рост молодежной безработицы. Определяются основные направления регулирования рынка труда молодежи.

Ключевые слова: безработица, молодежь, занятость, трудовая сфера, рынок труда.

\section{THE CURRENT STATE OF THE YOUTH LABOR MARKET IN RUSSIA}

\author{
L. O. Romashova \\ (Moscow University for the Humanities)
}

Abstract: The article examines the youth labor market in Russia to explain the causes of the rise in youth unemployment. We also suggest the main directions for regulating this segment of the labor market.

Keywords: unemployment, youth, employment, labor issues, labor market.

Социально-экономическое развитие в России, ее возрождение и стабилизация во многом зависят от молодежного фактора. Качество современной молодежи в первую очередь предопределяет будущий человеческий потенциал, так как представляет деятельную часть населения (Луков, Лапшин, 2010). Молодое поколение как будущий трудовой потенциал играет существенную роль в стабилизации общества, его динамического развития. Трудовой потенциал включает уровень профессионального образования, компетентность, нравственную зрелость, профессиональный опыт, предпринимательский навык. Возможности его реализации - одна из задач оптимальной занятости молодежи.

Положение молодежи в трудовой сфере во многом обусловлено сложившимися негативными тенденциями на рынке труда. Уязвимость мо- 
лодежного рынка труда определяется тем, что пока еще не созданы конкурентоспособные уровень и качество жизни, безопасность, экология и жилищные условия, причем на уровне передовых и развитых стран мира. Иначе лучшие молодые специалисты будут уезжать туда, где им удобнее жить, комфортнее и безопаснее работать, где созданы необходимые условия для научной и творческой деятельности.

Необходимо также отметить продолжающий спад производства, разбалансированность рыночной экономики, замедленное формирование хозяйственного механизма и в целом ухудшающейся экономической ситуации в стране. В связи с этим наблюдается регрессивный характер рынка труда. С разрушением системы гарантированной занятости и слабой социальной защиты отмечается скрытая безработица, падение реальной заработной платы, превращающаяся в минимальную социальную выплату, нарастают потоки занятости квалифицированной рабочей силы низким квалифицированным трудом. В соответствии с этим изменяется характер трудовой деятельности и отношение к нему как к основной социальной ценности. Труд постепенно превращается в средство выживания.

Острота проблем занятости и в ближайшие годы будет сохраняться. Это также связано с крайним дисбалансом спроса и предложений, неэффективным использованием трудовых ресурсов, слабой трудовой мотивацией, непродуманной политики государства на рынке труда. Coвременная экономика страны исключает возможность рыночного равновесия на рынке труда, а именно все больше увеличивается разрыв между продуктивной занятостью и нелегальной, а также между распределением трудовых ресурсов и реальным наличием рабочих мест. Все продолжает усугубляться кризис на рынке труда, выражающийся дисбалансом рабочих мест и трудовых ресурсов, а также нарастанием не регулируемого перемещения рабочей силы, ростом естественной текучести и издержками реформирования в трудовой сфере.

Растущая безработица для многих стала серьезной проблемой. В апреле 2015 г., по итогам выборочного обследования населения России по проблемам занятости 4,4 млн человек, или 5,8\% экономически активного населения, классифицировались как безработные (в соответствии с методологией Международной Организации Труда). В государственных учреждениях службы занятости населения в качестве безработных было зарегистрировано 1,0 млн человек, в том числе 0,8 млн человек получали пособие по безработице (2. Занятость и безработица, 2015: Электр. ресурс).

В ходе экономических преобразований наблюдается высвобождение значительного количества работников из сферы труда. Безусловно, эта проблема затронула и молодежь. Средний возраст безработных в апреле 2015 г. составил 36,1 года. Молодежь до 25 лет среди безработных состав- 
ляет $21,2 \%$, в том числе в возрасте $15-19$ лет $-4,1 \%, 20-24$ лет $-17,1 \%$. Высокий уровень безработицы отмечался в возрастной группе 15-19 лет $(31,4 \%)$ и $20-24$ лет $(13,4 \%)$. В среднем среди молодежи в возрасте $15-24$ лет уровень безработицы в апреле 2015 г. составил 15,1\%, в том числе среди городского населения - 13,8\%, среди сельского населения $-18,8 \%$. Коэффициент превышения уровня безработицы среди молодежи в среднем по возрастной группе 15-24 лет по сравнению с уровнем безработицы населения в возрасте 30-49 лет составляет 3,1 раза, в том числе среди городского населения $-3,3$ раза, сельского населения $-2,7$ раза (Занятость и безработица ..., Электр. ресурс).

Заметно ограничились реальные возможности трудоустройства молодых. Сокращается занятость молодежи в государственном секторе производства. Сужается сфера включения в бизнес и коммерческие структуры. Так, в 2014 г. было зафиксировано 235,7 тыс. малых предприятий или на 7 тыс. меньше по сравнению с 2011 г.

Молодежь в силу своего возраста не имеет достаточного профессионального и социального опыта, чтобы конкурировать с более квалифицированными и опытными работниками. По данным Госкомстата, в численности безработных 22,6\% составляют лица, не имеющие опыта трудовой деятельности. В апреле 2015 г. их численность составила 1 млн человек. В числе безработных, не имеющих опыта трудовой деятельности, 15,4\% составляет молодежь в возрасте от 15 до 19 лет, 43,0\% - от 20 до 24 лет, $22,9 \%$ - от 25 до 29 лет (там же). С возрастом у молодежи постепенно определяется профессиональный выбор, приобретается квалификация и некоторый жизненный опыт.

В связи с безработицей и сложностью трудоустройства снижается и жизненный уровень. Ухудшение материального положения сопровождается расслоением по уровню жизни большинства молодежи. Особенно это касается выпускников высших и средних специальных заведений, Многие из них подолгу не могут найти работу, и вынуждены искать неофициальные формы занятости. Доля безработных, ищущих работу один год и более, составляет 28,6 \%. Под влиянием этого фактора, чтобы поддерживать определенный уровень жизни, многие предприимчивые молодые люди выбирают антисоциальные сферы занятости, особенно это распространено среди несовершеннолетних.

Отсутствие работы, низкий уровень образования и слабая профессиональная подготовка, неадекватная оценка своих деловых способностей, отсутствие трудового интереса и плохое представление о профессиях - вот ряд обстоятельств, влияющих на сложность в определении своего профессионального места в жизни.

Значительное количество молодежи работают не по выбранной в учебном учреждении заведении специальности. Одни меняют специаль- 
ность, другие ищут более легкие, примитивные сферы занятости. Возникает противоречие между ожидаемым и действительным. Результативность профессиональной социализации и работы по специальности после окончания вуза остаются низкими. Действительное зависит от материальной стороны жизни: денег, связей в профессиональной среде, наличия неформальных связей и т. д. (Волокитина, 2010: 220).

Определенная часть молодых людей вовлекается во вторичную занятость. Вторичная занятость имеет положительные стороны (решение вопросов материального обеспечения, определенного прогрессивного влияния на формирование рынка труда, структуру занятости во многих отраслях и предприятиях и т. д.). Однако нельзя не учитывать отрицательные особенности этого процесса, связанного с тем, что вторичная занятость в основном редко помогает повысить квалификацию, не всегда связана с достижением желаемого профессионального статуса, тем самым как бы откладывает вопрос профессиональной карьеры на неопределенное время.

Нецивилизованные рыночные отношения, трудности экономических преобразований (падение жизненного уровня населения, инфляция, рост безработицы, падение престижа общественно значимого труда, рост преступности и т. д.) существенно влияют на трудовое поведение молодежи. Это привело к тому, что:

- профессиональная деятельность в сфере материального производства перестала быть в центре внимания и интересов работников, особенно молодежи;

- упал престиж высококвалифицированного и профессионального труда; определяющей стала ориентация на труд, дающий возможность много заработать при минимальных умственных и физических затратах;

- произошла ломка ценностных ориентаций; изменились отношения к профессии и труду;

- на периферии общественного сознания оказались мотивы общественного долга, добросовестного труда, его общественной пользы;

- массовое распространение получили идеология потребительства, социальная и трудовая пассивность;

- все еще продолжает воспроизводиться консервативный тип работника, вытесняется новатор.

В целом, если экстраполировать основные тенденции, можно говорить о том, что среди молодежи быстро растет настроение бесперспективности, безнадежности, отчуждение от профессионального труда, разочарование в демократии, неуверенность в своих силах, эмигрантские настроения, падение в нравственности, гипертрофирование индивидуального сознания и т. д. Но самое главное в этом процессе - это нарастание социальной апатии и негативное отношение к честному и произво- 
дительному труду.

Анализ рынка труда молодежи показал, что необходимо разрабатывать активную политику занятости. Регулирование рынка труда необходимо осуществлять по следующим направлениям:

- содействие трудоустройству путем создания новых рабочих мест;

- подготовка кадров с учетом современных требований и потребностей общества;

- создание социально-экономических, политико-правовых, организованных условий, трудовых гарантий и возможностей в интересах общества;

- разработка государственных программ по молодежной занятости;

- организация специализированных институтов по трудоустройству, профессиональному консультированию;

• создание широкомасштабной доступной информации о наличии свободных рабочих мест и имеющейся рабочей силы.

Кроме того, решение молодежных профессиональных проблем, в том числе и по проблеме безработицы, требует разработки и реализации более гибкой политики в сфере труда на общероссийском уровне. Исходным условием регулирования рынка труда молодежи должна стать организация оперативного анализа спроса на рабочую силу и предложения рабочих мест со стороны предприятий различной формы собственности, квотирование рабочих мест для молодежи, а также выявление ее ориентации при выборе сферы занятости и места работы. В связи с этим целесообразно широко использовать финансово-кредитные рычаги, которые защищали бы интересы молодых тружеников и стимулировали их труд. С помощью этих рычагов можно регулировать условия, вызывающие перелив рабочей силы с государственных предприятий в частные и с легальных и нелегальных форм занятости и т. Д. Данную проблему, как об этом красноречиво говорит зарубежный опыт, в определенной степени может решить развитие мелкого бизнеса и предпринимательства. Поэтому этим структурам необходимо не только создавать щадящие условия для их создания и функционирования, но и стимулировать их развитие.

\section{СПИСОК ЛИТЕРАТУРЫ}

2. Занятость и безработица [Электронный ресурс] // Федеральная Службы государственной статистики. URL: http://www.gks.ru/bgd/regl/ b15_01/IssWWW.exe/Stg/d04/3-2.doc (дата обращения: 14.06.2015).

Волокитина, А. А. (2010) Жизненные стратегии молодежи в условиях профессионального выбора // Знание Понимание Умение. № 4. С. 216221.

Занятость и безработица в Российской Федерации в апреле 2015 г. (по итогам обследований населения по проблемам занятости) [Электронный 
ресурс] // Федеральная Службы государственной статистики. URL: http:// www.gks.ru/bgd/free/b04_03/IssWWW.exe/Stg/d05/99.htm (дата обращения: 14.06.2015).

Луков, В. А., Лапшин, В. А. (2010) Человеческий потенциал и повседневность // Знание. Понимание. Умение. № 3. С. 211-215.

Ромашова Людмила Олеговна - кандидат социологических наук, доцент кафедры социологии Московского гуманитарного университета. Адрес: 111395, Россия, г. Москва, ул. Юности, д. 5 . Тел.: + 7 (495) 374-60-21. Эл. адрес: LOR7@yandex.ru

Romashova Lyudmila Olegovna, Candidate of Sociology, Associate Professor, Department of Sociology, Moscow University for the Humanities. Postal address 5 Yunosti St., 111395 Moscow, Russian Federation. Tel.: + 7 (495) 374-60-21.E-mail: LOR7@yandex.ru 